\title{
Preparation and in vitro \& in vivo evaluation of cephalexin matrix tablets
}

\author{
Boi Basanta Kumar Reddy ${ }^{*}$, Kambhayathughar Eswara Venkata Nagoji², Satyanarayan Sahoo ${ }^{3}$ \\ ${ }^{1}$ Srinivasarao College of Pharmacy, Pharmaceutical Technology Department, Pothina Mallayya Palem, Visakhapatnam, AP, \\ India, ${ }^{2}$ Sri Venkateswara College of Pharmacy, Pharmaceutical Technology Department, Etcherla, Srikakulam, AP, India, \\ ${ }^{3}$ Post Graduate Department of Chemistry, Berhampur University, Bhanja Bihar, Berhampur, Odisha, India
}

\begin{abstract}
The purpose of the study is to develop cephalexin controlled-release matrix tablets by using lower proportions of release retardant polymer and to establish their in vitro \& in vivo correlation. Tablets were compressed by incorporating polymers in a matrix form along with drug which prolong the drug release. Twelve formulations were prepared by mixing ethyl cellulose (EC) and hydroxypropyl methylcellulose (HPMC) (three different viscosity grades) in various proportions. F-1 to F-4 formulations were prepared by incorporating drug, HPMC K4M and ethyl cellulose in $100: 5: 5,100: 10: 5,100: 15: 5$ and $100: 20: 5$; similarly, F-5 to F-8 were prepared with HPMC K15M; and F-9 to F-12 were prepared with HPMC K100M using a wet granulation process maintained same proportions, along with drug and EC. Tablets were evaluated for their pre-compression and post-compression characteristics and they were found to be in limits. From the dissolution testing, F-4 showed 100.34\% medicament release in $12 \mathrm{~h}$. In vivo studies were conducted on rabbit and pharmacokinetic parameters of the optimized formulation were evaluated using HPLC method. It was found that matrix tablets showed increased $t_{1 / 2}$ and decreased $\mathrm{K}_{\mathrm{el}}$. The design signified that the drug release rate from tablets was influenced by the small proportion (around $7 \%$ of a tablet weight) of polymer mixture and it controlled $100 \%$ medicament release upto $12 \mathrm{~h}$ effectively with the low grade viscosity of HPMC combination, with good in vitro \& in vivo correlation.
\end{abstract}

Keywords: Matrix tablets. Polymer mixture. Release kinetics. Pharmacokinetics parameters. In vitro \& in vivo correlation.

\section{INTRODUCTION}

In developing countries, people get infected very often. Generally, disease causing agents are both gram positive and gram negative bacteria, thus proper treatment should be taken with medicaments, which have efficient action to neutralize the activity of these microorganisms. All cephalosporins posses a wide range of bactericidal activities. Cephalexin is a first generation cephalosporin, and it is an orally active drug. It inhibits cell wall synthesis of gram-positive bacteria (Sirisolla, Ramanamurthy, 2015; Tripathi, 2013; Reddy, Nagoji, Patnaik, 2015; Reddy, Nagoji, Sahoo, 2016). The intension of controlled release systems is used to decrease dosage regimen and maintain steady-state levels. Thus, it posses better control over acute

\footnotetext{
*Correspondence: B. B. K. Reddy. Srinivasarao College of Pharmacy, Pharmaceutical Technology Dept., P.M.Palem, Visakhapatnam-530041, AP, India. E-mail: bbasantareddy9@gmail.com
}

diseases, with maximum utilization of drug by enabling a reduction in the total amount of the dose administered and leads patient compliance (Chugh et al., 2012). In this work, a series of trial has been made to design, formulate and evaluate in vitro release of cephalexin matrix to establish drug release upto $12 \mathrm{~h}$, as the work was done previously for $6 \mathrm{~h}$ release matrix tablets (Vijay et al., 2012). The formation of the matrix system with the release retardant polymer affects the drug release for an extended period of time with complete utilization of the drug. The wet granulation process is implemented for tablet compression. The cephalexin matrix tablets are designed by using EC and HPMC (HPMC K4M/HPMC K15M/HPMC 100M) in different proportion such as $5 \mathrm{mg}: 5 \mathrm{mg}, 5 \mathrm{mg}$ : $10 \mathrm{mg}$, $5 \mathrm{mg}: 15 \mathrm{mg}$ and $5 \mathrm{mg}: 20 \mathrm{mg}$. In all formulations, the EC quantity is fixed at $5 \mathrm{mg}$, and added HPMC grades in a range of $5 \mathrm{mg}$ to $20 \mathrm{mg}$ to EC, to prepare polymer mixture. Twelve formulations were evaluated for their various parameters, i.e., before $\&$ after the tablet compression 
parameters; and pharmacokinetic parameters evaluation of the optimized formulation (Gennaro, 2001). The polymer mixture is used in a range of 2.85 to $7.14 \%$ of the tablet weight, which are very low proportions of polymer blend to establish the in vitro release of the drug upto $12 \mathrm{~h}$. The effect of matrix polymer over evaluated parameters such as drug release rate, cumulative $\%$ drug released and drug released mechanism, and pharmacokinetic parameters were studied (Reddy, Nagoji, Sahoo, 2016).

\section{MATERIAL AND METHODS}

Cephalexin was gift sample from Ranbaxy Lab, Gudgaon, HPMC K4M, HPMC K15M, HPMC K100M, EC, Dibasic calcium phosphate, Magnesium stearate and Talc used are of analytical grade.

\section{Fourier Transform Infrared (FTIR) spectroscopy}

FTIR studies were carried out on pure drug, individual polymer and optimized formulation. An equal weight of the sample and potassium bromide (about $1 \mathrm{mg}$ each) was mixed and compressed to form a pellet and scanned in the range of 400 to $4000 \mathrm{~cm}^{-1}$ (Reddy, Nagoji, Sahoo, 2016).

\section{Differential Scanning Calorimetry (DSC)}

DSC studies were carried out between drug and excipients to establish chemical interactions. Basically, the thermal attributes of a physical mixture are the sum of the thermal properties of individual components (Reddy, Nagoji, Sahoo, 2016).

\section{Formulation of controlled release matrix tablets}

Required quantities of drug and all excipients were passed through the sieve 44 \# and then weighed accurately and blended properly (except lubricant and glidant) as per the formula (in Table I). The wet damp mass was formed by slowly adding distilled water q.s (quantity sufficient) as granulating liquid. The cohesive material was sieved through sieve 12 \# to form wet granules. Granules were dried at $50{ }^{\circ} \mathrm{C}$ for $2 \mathrm{~h}$ in a hot air oven (Universal Hot Air Oven) and then passed through 22 \# mesh to collect uniform size of the granules. Talc and magnesium stearate were added to lubricate the granules and then compressed them with the help of a single punch-tableting machine (Shakti) with tablet hardness maintained in the range of 4 to $6.02 \mathrm{~kg} / \mathrm{cm}^{2}$ (Rezal, Qadir, Haider, 2003; Andreopopulas, Tarantilli, 2001; Parikh, 2005).

\section{Pre-compression evaluation parameters}

The ratio of a certain weight of the granules to their bulk volume is called as bulk density. Teknik Bulk Density Apparatus was used to measure bulk density. Pre-sieved granules were placed into a graduated measuring cylinder and then the bulk density was calculated by measuring the weight and volume (Basak, 2004; Aulton, 2002). It was repeated for three times. The ratio of a certain weight of the granules to their tapped volume is called as tapped density. The granules were filled in a graduate measuring cylinder with tap density tester, and operates for a certain number of taps until the granules volume reaches a minimum, and then the tapped density was calculated. It was repeated for three times (Reddy, Nagoji, Patnaik, 2015; Aulton, 2002;

TABLE I - Composition of tablet formulations

\begin{tabular}{|c|c|c|c|c|c|c|c|c|c|c|c|c|}
\hline Ingredients & F-1 & F-2 & F-3 & F-4 & F-5 & F-6 & F-7 & F-8 & F-9 & F-10 & F-11 & F-12 \\
\hline Cephalexin & 100 & 100 & 100 & 100 & 100 & 100 & 100 & 100 & 100 & 100 & 100 & 100 \\
\hline Ethyl cellulose & 5 & 5 & 5 & 5 & 5 & 5 & 5 & 5 & 5 & 5 & 5 & 5 \\
\hline *HPMC K4M & 5 & 10 & 15 & 20 & -- & -- & -- & -- & -- & -- & -- & -- \\
\hline *HPMC K15M & -- & -- & -- & -- & 5 & 10 & 15 & 20 & -- & -- & -- & -- \\
\hline *HPMC K100M & -- & --- & -- & -- & -- & -- & -- & -- & 5 & 10 & 15 & 20 \\
\hline $\mathrm{DCP} * *$ & 230 & 225 & 220 & 215 & 230 & 225 & 220 & 215 & 230 & 225 & 220 & 215 \\
\hline Talc & 5 & 5 & 5 & 5 & 5 & 5 & 5 & 5 & 5 & 5 & 5 & 5 \\
\hline Magnesium stearate & 5 & 5 & 5 & 5 & 5 & 5 & 5 & 5 & 5 & 5 & 5 & 5 \\
\hline Distilled water (in $\mathrm{mL}$ ) & q.s & q.s & q.s & q.s & q.s & q.s & q.s & q.s & q.s & q.s & q.s & q.s \\
\hline $\begin{array}{l}\text { Total weight of tablet } \\
\text { (in mg) }\end{array}$ & 350 & 350 & 350 & 350 & 350 & 350 & 350 & 350 & 350 & 350 & 350 & 350 \\
\hline
\end{tabular}

* HPMC is Hydroxypropyl methylcellulose; **DCP is dicalcium phosphate 
Shabaraya, Narayanacharyulu, 2008).

Hausner's ratio was calculated as the ratio of tapped density to bulk density. Carr's index was calculated as the ratio of the difference between tapped density and bulk density to the tapped density, multiplied by 100 . It was repeated for three times (Aulton, 2002; Shirwaikar, Jacob, Grover, 2005). Repose angle $(\theta)$ can be defined as the angle between the surface of a pile of granules and the diameter of the cone base; it was calculated by pouring the weighed granules into the glass funnel which was firmed to a stand at a height of $3 \mathrm{~cm}$. The granules were passed through the funnel onto the surface of a graph paper to form a cone. Then the height $(\mathrm{h})$ and diameter (d) of the cone were measured and the repose angle was calculated. Three trials were carried out (Lachman, Lieberman, 2009; Cooper, Gunn, 1986). The repose angle can be measured using the formula,

$$
\theta=\tan ^{-1}\left(\frac{2 h}{d}\right)
$$

\section{Post-compression evaluation for formulated matrix tablets}

Tension requires to break a compressed tablet diametrically is called hardness. The Monsanto hardness tester was used to determine the hardness of the tablet. Six tablets were used for the hardness measurement (Indian Pharmacopoeia, 2010). As per European Pharmacopoeia (EP), twenty tablets were randomly taken for the calculation of the weight variation test and their average weight was determined. Individual tablets weights were compared with the average weight (Sirisolla, Ramanamurthy, 2015; Lachman, Lieberman, 2009; Krishanaiah et al., 2003). Three tablets were randomly selected for the measurement of thickness. The tablet was placed between two arms of the vernier calipers and thickness was measured (Indian Pharmacopoeia, 2010). 10 tablets were selected randomly and put inside the Roche friability test apparatus (Teknik) for the determination of friability. Initially 10 tablets were weighed and then they were revolved in a drum for four minutes. Then, the tablets were dedusted, reweighed and the lost quantity was calculated and expressed into percentage value (Indian Pharmacopoeia, 2010; Chaudhari, 2005).

Randomly ten tablets were taken, the total weight and the average weight were calculated and they were grinded individually to fine powder. Powder equivalent to $355.6 \mathrm{mg}$ of cephalexin was transferred to a volumetric flask ( $100 \mathrm{~mL}$ capacity), added $80 \mathrm{~mL}$ of $0.1 \mathrm{~N} \mathrm{HCl}$ buffer to dissolve completely and then made upto $100 \mathrm{~mL}$ with the buffer solution. Then the whole contents were filtered through a Whatman filter paper. Few sample solutions were placed in a cuvette and the absorbance were noted down using UV-Vis spectrophotometer (Systronic 2203) and quantity of the drug in the sample was calculated. Similarly, the drug solution prepared in phosphate buffer of pH 6.8 and quantity of the drug in the sample was calculated (Indian Pharmacopoeia, 2010).

In vitro dissolutions of controlled release tablets of cephalexin were studied in USP XXIII dissolution apparatus (Electrolab) rotated at $100 \mathrm{rpm}$. Dissolution was carried out in $900 \mathrm{~mL}$ of $0.1 \mathrm{~N} \mathrm{HCl}$ buffer for $2 \mathrm{~h}$, then in phosphate buffer of $\mathrm{pH} 6.8$ up to $12 \mathrm{~h}$. The dissolution media used for the test was maintained at $37{ }^{\circ} \mathrm{C} \pm 0.5^{\circ} \mathrm{C}$ temperature throughout the experiment and one tablet was used in each test. At predetermined time intervals, each time $5 \mathrm{~mL}$ of samples were pulled out from the dissolution medium using a syringe fitted with a pre-filter and immediately $5 \mathrm{~mL}$ of pure quantity of dissolution media was replaced after each withdrawal of samples. The absorbance of the withdrawn samples was analyzed at 262 $\mathrm{nm}$ and the drug content was calculated. The dissolution studies were carried out for three determinations. The cumulative percent drug released was calculated and the dissolution graph was plotted by placing time on $\mathrm{X}$-axis and cumulative percent drug released on Y-axis (Indian Pharmacopoeia, 2010; Raparla, Murthy, 2007).

Zero and first order rate of reaction were calculated by incorporating dissolutions data obtained from 12 formulations. Cumulative amount of drug released to time graph, represents zero order release and the equation is expressed as, $\mathrm{C}=\mathrm{K}_{0} \mathrm{t}$, where $\mathrm{K}_{0}$ is the zero order rate constant and $t$ is the time (in $h$ ). Log cumulative $\%$ of the drug remained vs. time graph, represents a first order release, and the equation is, $\log C=\log \mathrm{C}_{0}-(\mathrm{Kt} / 2.303)$, where $\mathrm{C}_{0}$ is the concentration of drug at zero time, $\mathrm{K}$ is the first-order constant and $t$ is the time (Wagner, 1969).

A cumulative $\%$ drug released vs. square root of time graph, denotes Higuchi model and the equation is, $\mathrm{Q}=\mathrm{K} \mathrm{t}^{1 / 2}$, where $\mathrm{K}$ is the constant expresses the design variables of the system and $t$ is the time (in $h$ ). The equation signifies the drug release rate is inversely depends on the square root of time (Higuchi, 1963). Korsmeyer Peppas (KP) equation is used to determine the drug release mechanism from the dosage form. $12 \mathrm{~h}$ dissolutions data on drug release were plotted using the KP equation, i.e., $\log$ cumulative $\%$ drug released vs. long time, and then exponent ' $n$ ' was calculated. $M_{t} / M_{\infty}=K t^{n}$, where $M_{t} / M_{\infty}$ is the fractional solute release, $\mathrm{t}$ is the release time, $\mathrm{K}$ is a kinetic constant characteristic of the drug/polymer system, and ' $\mathrm{n}$ ' is an exponent that characterizes the mechanism 
of release of tracers. For cylindrical matrix tablets, if the exponent $\mathrm{n}=0.45$, it is Fickian diffusion; if $0.45<\mathrm{n}<0.89$, it is non Fickian or anomalous diffusion; and if $n=0.89$, it expresses Case-II Transport or typical Zero order release (Korsmeyer et al., 1983).

In vivo analysis was performed by using Cyber lab Scientific Instruments liquid chromatography system composed of a LC-10AT pump, a SPD-10A UV detector, an ODS C-18 column (150 mm x $4.6 \mathrm{~mm}$ I.D., $5 \mu \mathrm{m}$ particle size) $25 \mu \mathrm{L}$ Hamilton injection syringe. Mobile phase consisted of a mixture of $2 \mathrm{mM}$ phosphate buffer: Acetonitrile: $(50: 50, \% \mathrm{v} / \mathrm{v})$, adjusted to $\mathrm{pH} 3.5$ to $1 \%$ orthophosphoric acid. The drug was eluted isocratically at a mobile phase flow rate of $1.2 \mathrm{~mL} / \mathrm{min}$ and monitored with a UV detector operating at $254 \mathrm{~nm} .500 \mu \mathrm{L}$ of mobile phase were used for the preparation of each sample and vortexed for $30 \mathrm{sec}$; and then $20 \mu \mathrm{L}$ of it was injected into the HPLC system. Calibration curve was plotted by using a concentration range of $0.025-3.2 \mu \mathrm{g} / \mathrm{mL}$ of cephalexin; and showed linearity in between the concentration of cephalexin and its peak area $\left(\mathrm{R}^{2}=0.9990\right)$.

The optimized matrix tablets were further evaluated for their pharmacokinetic parameters. The pharmacokinetic study protocol was approved by the IAEC (Reg. No. 1263/bc/16/CPCSEA). Six male adult rabbits weighing about 2.5 to $3.5 \mathrm{~kg}$ range were selected for the study. Food was withdrawn from the rabbits 12 $\mathrm{h}$ before drug administration and until $12 \mathrm{~h}$ post dosing, but they had free access to water throughout the study. The study was conducted as parallel design in which a single dose $1.8 \mathrm{mg}$ was administered to rabbits orally. The animals were divided into 2 groups containing 3 animals in each. For one group pure cephalexin was given with water and for another group matrix tablet was given. At $0.25 \mathrm{~h}, 0.5 \mathrm{~h}, 1.0 \mathrm{~h}, 1.5 \mathrm{~h}, 2 \mathrm{~h}, 3 \mathrm{~h}, 4 \mathrm{~h}$, $6 \mathrm{~h}, 8 \mathrm{~h}$ and $12 \mathrm{~h}$ time, blood samples were pulled from the marginal ear vein of rabbit; and then the collected samples were centrifuged for 10 minutes at 2500-3500 rpm using Micro centrifuge (Remi Equipment, Mumbai, India). Immediately after centrifugation, samples were stored in refrigeration condition until the analysis was performed. Safety aspects were evaluated by monitoring adverse effects and vital symptoms and through physical examination.

\section{RESULTS AND DISCUSSION}

IR spectrum of the pure drug, polymers and power mixtures of the drug, excipients $\&$ the polymers were taken. The characteristic peaks of cephalexin were obtained at $3273.31 \mathrm{~cm}^{-1}, 3056.31 \mathrm{~cm}^{-1}, 2884.64 \mathrm{~cm}^{-1}, 1759.14 \mathrm{~cm}^{-1}$, $1693.56 \mathrm{~cm}^{-1}, 1396.51 \mathrm{~cm}^{-1}, 1281.74 \mathrm{~cm}^{-1}, 1196.87 \mathrm{~cm}^{-1}$, $1071.49 \mathrm{~cm}^{-1}, 986.62 \mathrm{~cm}^{-1}, 818.81 \mathrm{~cm}^{-1}, 696.33 \mathrm{~cm}^{-1}$ and $581.56 \mathrm{~cm}^{-1}$ (in Figure 1 to 4 ). In DSC test, drug peak was

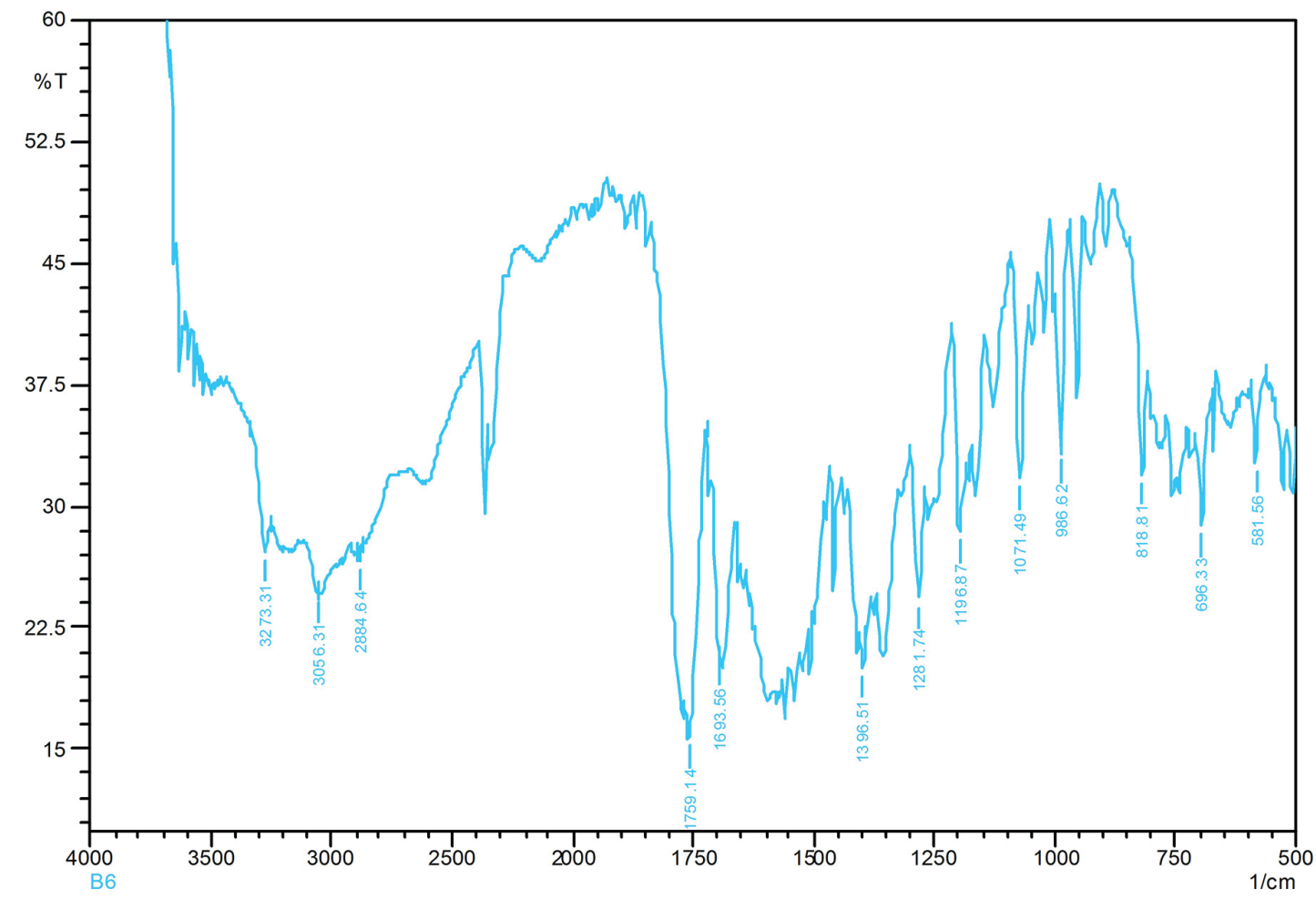

FIGURE 1 - IR Spectrum of cephalexin alone. 
observed at $199.1{ }^{\circ} \mathrm{C}$ in drug-polymer mixture, whereas for the pure drug showed an endothermic peak was obtained at $191.34{ }^{\circ} \mathrm{C}$ (in Figure 5 and 6 ). The obtained FT-IR spectra indicated good compatibility in between drug and excipients. Thermogram peaks indicated there was no phase transformation in between the drug and polymers.

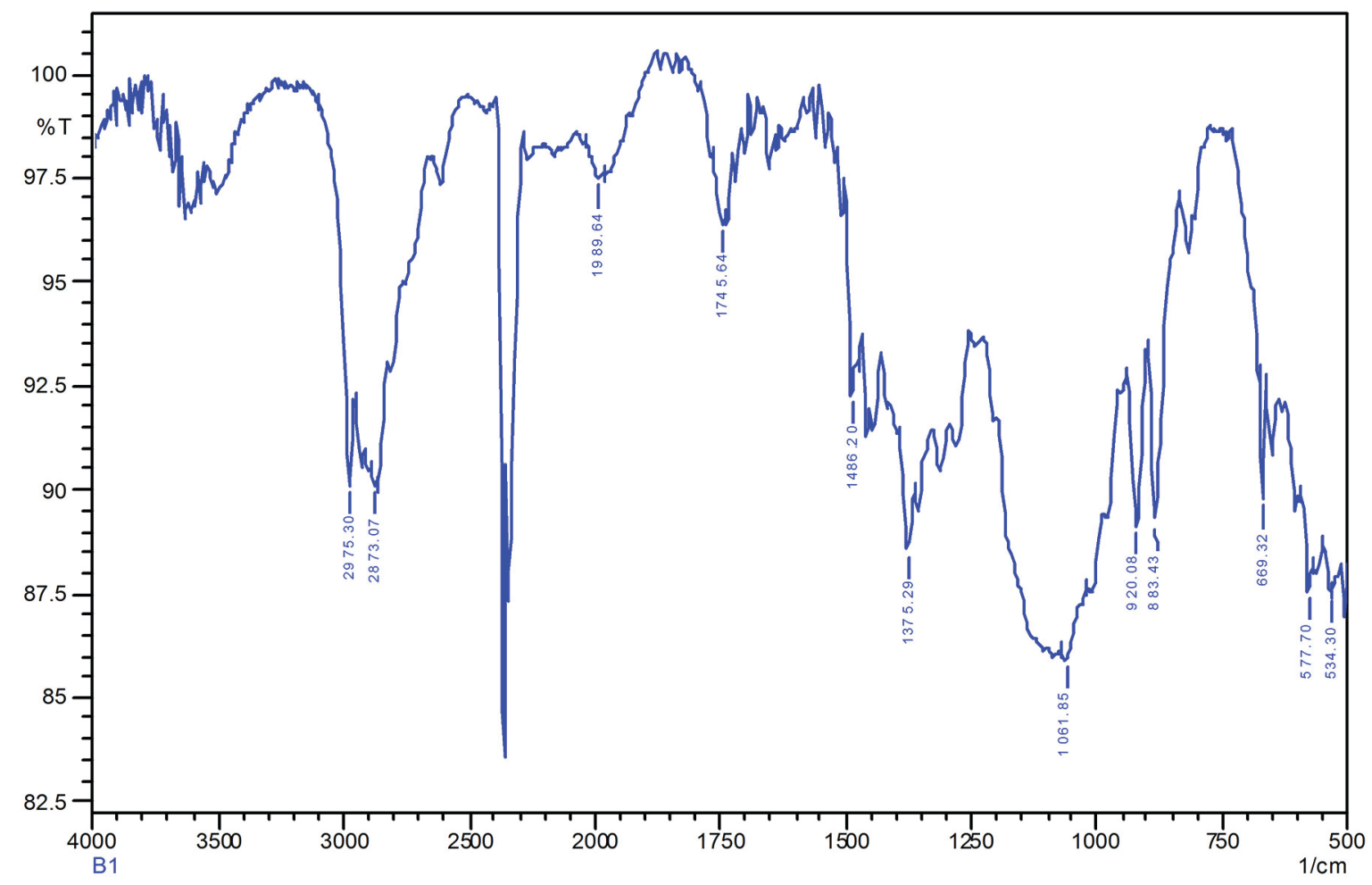

FIGURE 2 - IR Spectrum of ethyl cellulose alone.

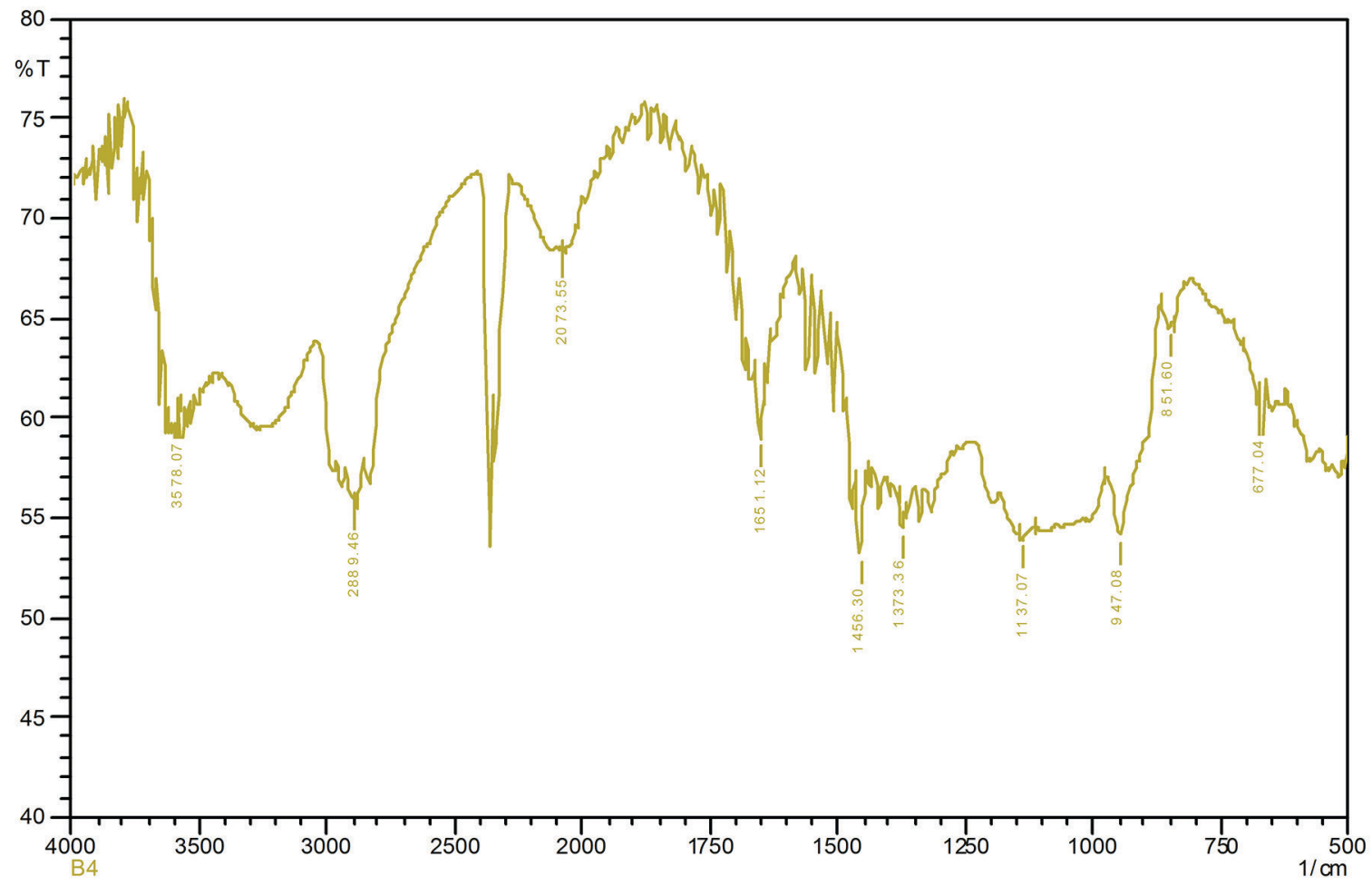

FIGURE 3 - IR Spectrum of HPMC K4M alone. 
Bulk and tapped densities of the granules of twelve formulations were calculated and they ranged from 0.365 to $0.394 \mathrm{~g} / \mathrm{mL}$ and from 0.420 to $0.461 \mathrm{~g} / \mathrm{mL}$ respectively (in Table II). For granules, there were no

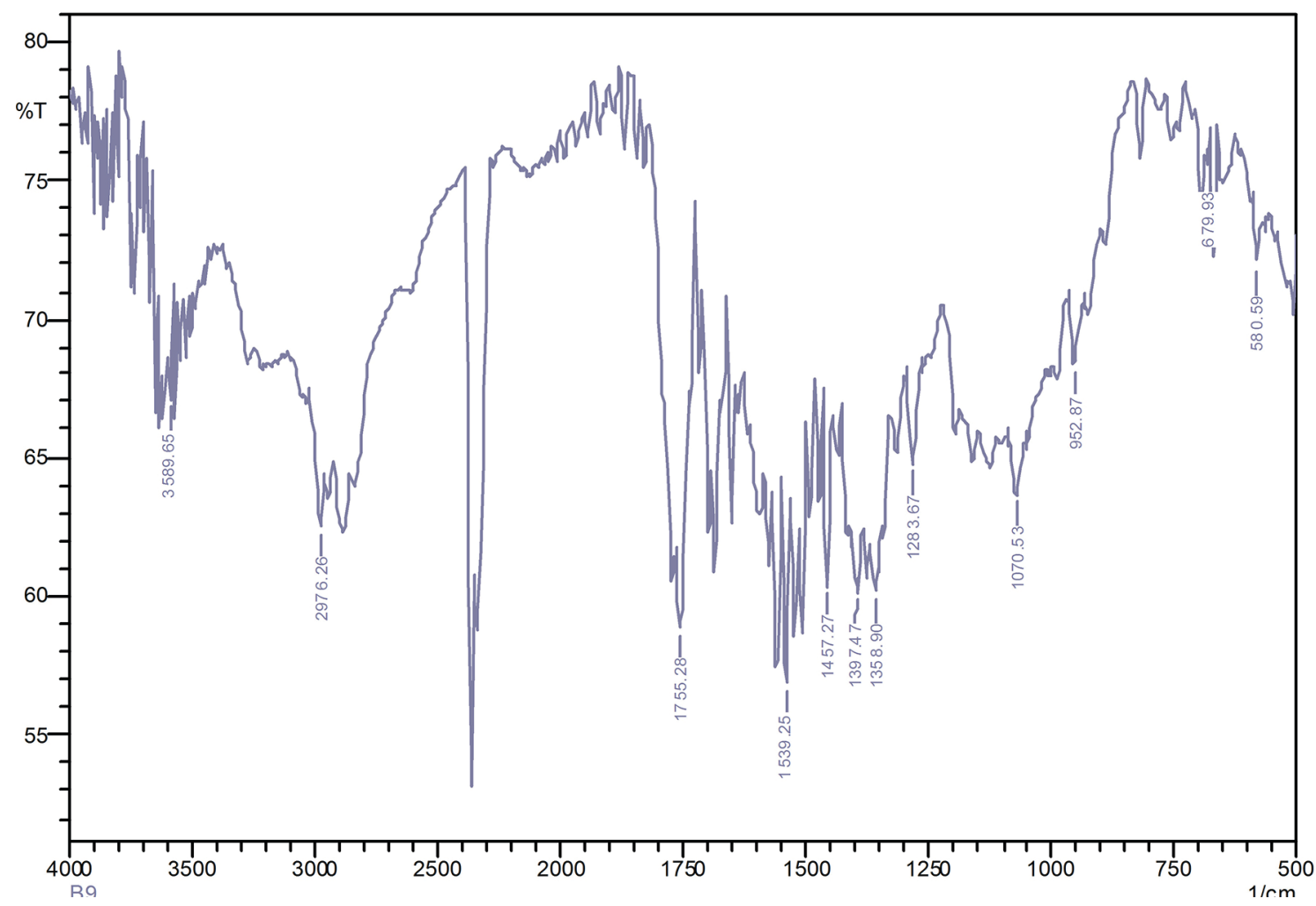

FIGURE 4 - IR Spectrum of cephalexin, with excipients and polymers.

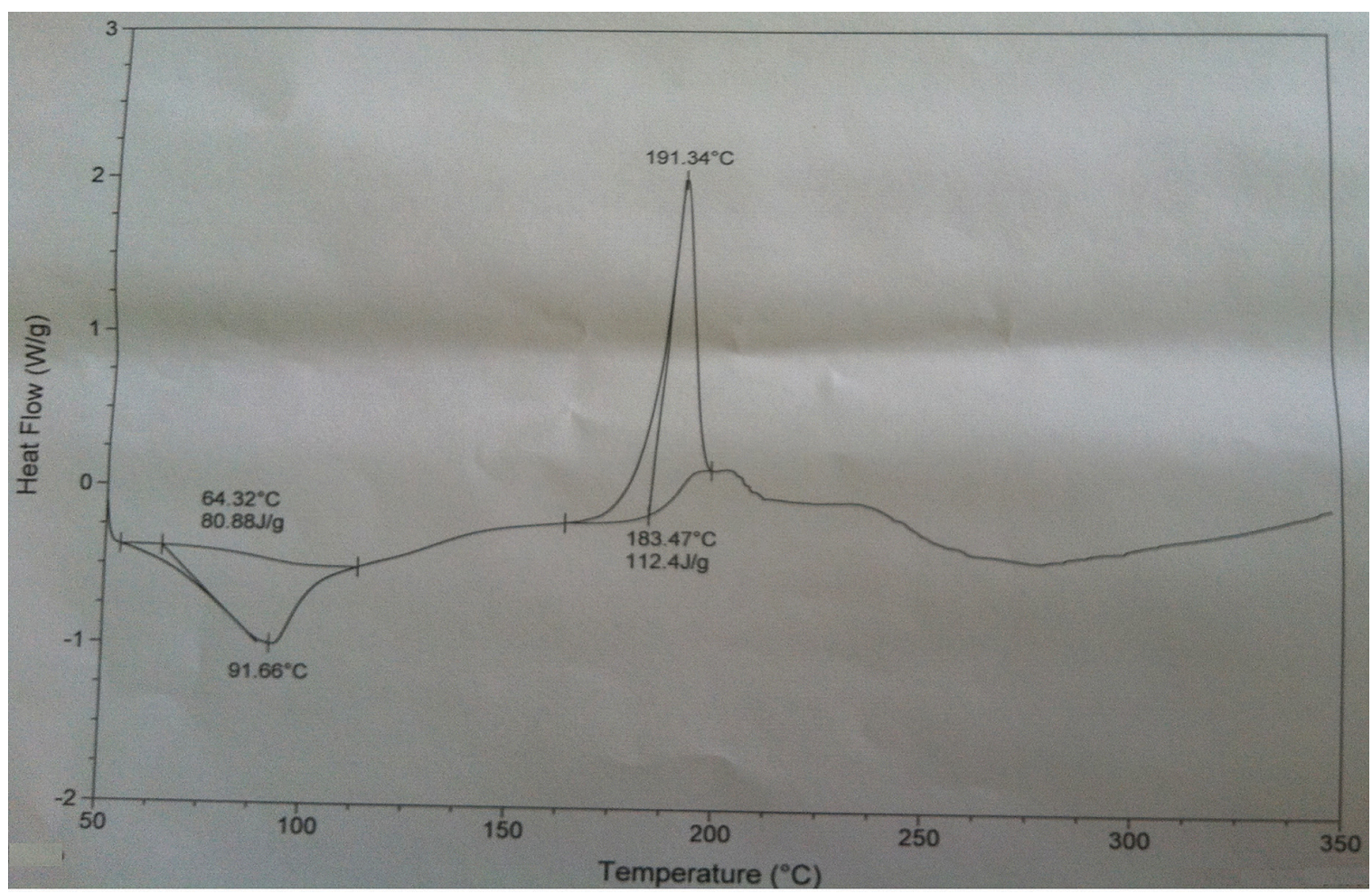

FIGURE 5 - Thermogram of pure drug. 


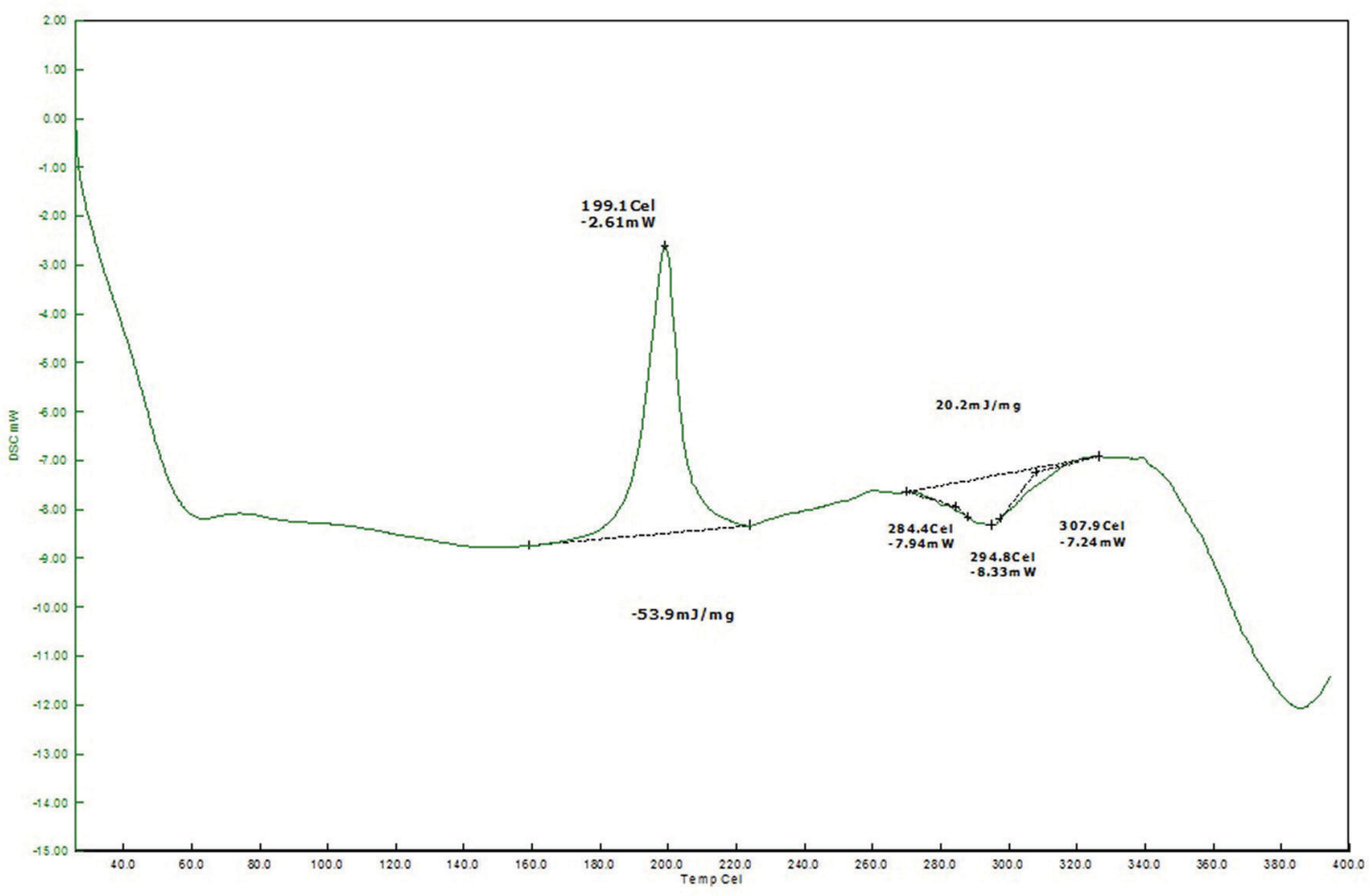

FIGURE 6 - Thermogram of drug and polymers.

significant differences in between bulk density and tapped density, indicated good granules distribution in the compressed matrix tablets. The Hausner's ratio values ranged from 1.114 to 1.197 , and the Carr's index values ranged from 12.18 to $14.53 \%$. Hausner's ratio values were less than 1.25 indicating good flow and it was observed to be within pharmacopoeia limits. Generally, Carr's index values between 5-15 indicate excellent flow property; and the results obtained indicated that the power flow properties were within the pharmacopoeias limits. Angle of repose values ranged from $23.24^{\circ}$ to $25.63^{\circ}$ (in Table II). Angle of repose indicated good flow properties of granules as its value was less than $25.63^{\circ}$, and it was observed to be within the official standard limits.

The hardness of all the formulations ranged from 5.52 to $6.02 \mathrm{~kg} / \mathrm{cm}^{2}$. The thickness of all the formulations

TABLE II - Precompression parameters of the granules

\begin{tabular}{cccccc}
\hline $\begin{array}{c}\text { Formulation } \\
\text { Code }\end{array}$ & $\begin{array}{c}\text { Bulk Density } \\
(\mathbf{g} / \mathbf{m L})\end{array}$ & $\begin{array}{c}\text { Tapped Density } \\
(\mathbf{g} / \mathbf{m L})\end{array}$ & $\begin{array}{c}\text { Carr's Index } \\
(\mathbf{\%})\end{array}$ & $\begin{array}{c}\text { Hausner's } \\
\text { ratio } \pm \text { SD }\end{array}$ & Angle of repose \\
\hline F-1 & 0.384 & 0.441 & 12.92 & $1.148 \pm 0.03$ & $25.41^{\circ}$ \\
F-2 & 0.379 & 0.434 & 12.67 & $1.145 \pm 0.04$ & $23.24^{\circ}$ \\
F-3 & 0.394 & 0.461 & 14.53 & $1.170 \pm 0.03$ & $24.32^{\circ}$ \\
F-4 & 0.370 & 0.422 & 12.32 & $1.140 \pm 0.04$ & $25.63^{\circ}$ \\
F-5 & 0.369 & 0.428 & 12.18 & $1.149 \pm 0.06$ & $24.21^{\circ}$ \\
F-6 & 0.365 & 0.437 & 14.47 & $1.197 \pm 0.01$ & $24.74^{\circ}$ \\
F-7 & 0.372 & 0.428 & 13.08 & $1.150 \pm 0.03$ & $25.62^{\circ}$ \\
F-8 & 0.384 & 0.420 & 12.28 & $1.114 \pm 0.03$ & $24.37^{\circ}$ \\
F-9 & 0.370 & 0.422 & 12.32 & $1.140 \pm 0.06$ & $23.38^{\circ}$ \\
F-10 & 0.375 & 0.421 & 12.32 & $1.135 \pm 0.01$ & $24.34^{\circ}$ \\
F-11 & 0.380 & 0.432 & 12.23 & $1.142 \pm 0.03$ & $25.12^{\circ}$ \\
F-12 & 0.371 & 0.425 & 13.26 & $1.190 \pm 0.04$ & $25.10^{\circ}$ \\
\hline
\end{tabular}

All values are mean \pm standard deviation (SD) for $n=3$ determination 
was between 2.30 to $2.35 \mathrm{~mm}$. For matrix tablets, the mean thickness was almost uniform in all the formulations. The weights of the tablets were between 1.71 to $2.30 \%$, as the actual weight of the tablet was $350 \mathrm{mg}$. The Pharmacopoeial specification for weight variation limit is $\pm 5 \%$ for uncoated tablets weighing more than $324 \mathrm{mg}$. Hence all the formulations were passed the weight variation test.

Friability of all the formulations was determined, and the values were in the range from 0.32 to $0.82 \%$. Percent drug content of cephalexin was within 98.48 to $99.30 \%$ for all the twelve formulations (in Table III). Friability of the formulated tablets was found to be below $1 \%$, which indicated good mechanical resistance of the tablets. Hence all the formulations were within the Pharmacopoeial limits. Based on the obtained results, percent drug content of the drug in all the formulated tablets was found to be within limit, and indicated uniformity of mixing.

Results obtained in the in vitro drug release study of different formulations are shown in Table IV. The data indicated that formulations from F-1 to F-12, released $92.34 \%, 93.89 \%, 94.36 \%, 100.34 \%, 89.91 \%, 90.6 \%$, $91.63 \%, 92.5 \%, 92.48 \%, 95.41 \%, 95.48 \%$ and $97.47 \%$ of the drug respectively at the end of $12 \mathrm{~h}$. Based on obtained in vitro drug release dissolution data, it was observed that, the $\%$ of drug release gradually increased from $\mathrm{F}-1$ to F-4 i.e., $92.34 \%, 93.89 \%, 94.36 \%$, and $100.34 \%$, respectively, from F-5 to F-8 i.e., $89.91 \%$, 90.6\%, $91.63 \%$, and $92.5 \%$, respectively, and from F-9 to F-12 i.e., $92.48 \%, 95.41 \%, 95.48 \%$ and $97.47 \%$ respectively, at the end of $12 \mathrm{~h}$. From the in vitro release data profile, it was observed that when individual HPMC grade polymer concentration increases in the formulations, it increases $\%$ drug release from the dosage form, i.e., $\mathrm{F}-1<\mathrm{F}-2<\mathrm{F}-3$ $<$ F-4 (K4M used formulations), F-5 $<$ F- $6<$ F-7 $<$ F-8 (K15M used formulations), and F-9 $<$ F-10 $<$ F-11 $<$ F-12 (K100M used formulations). Based on $\%$ of drug release, F-1, F-2, F-3, F-5, F-6, F-7, F-8, F-9, F-10 and F-11 formulations could not able to release more than $90 \%$ and $95.48 \%$ of the drug at $10 \mathrm{~h}$ and $12 \mathrm{~h}$ respectively i.e., they hardly released approximately $5.48 \%$ drug in last two hours in comparison to F-4 and F-12 formulations, which was not complied to the intended study design; and it was found that their polymer combination were not in appropriate ratio to control the drug release, where as formulations F-4 and F-12 were released the drug in controlled and efficient manner upto $12 \mathrm{~h}$, and their\% released were 100.34 and 97.47 respectively. From the data obtained from different formulations, it was concluded that the formulation F-4 (EC: HPMC K4M in $5 \mathrm{mg}$ : $20 \mathrm{mg}$ ratio) released $100.34 \%$ of cephalexin in $12 \mathrm{~h}$ could be optimized as the best formulation as it prevailed $100 \%$ release of the drug.

Data of in vitro release were fitted to different equation and kinetic models to explain the release kinetics of cephalexin from the controlled release matrix tablet. Estimated data were plotted according to the zero order equation and first order equation, the formulations showed with regression values between 0.9548 and 0.9899 in zeroorder, \& 0.9460 and 0.9747 in first order (in Table V).

From the data obtained from different formulations, zero order release rate constant showed fairly linearity

TABLE III - Evaluation parameters of the compressed tablets

\begin{tabular}{cccccc}
\hline $\begin{array}{c}\text { Formulation } \\
\text { Code }\end{array}$ & $\begin{array}{c}\text { Thickness } \\
(\mathbf{m m}) \pm \mathbf{S D}\end{array}$ & $\begin{array}{c}\text { Weight variation } \\
\mathbf{( \% )}\end{array}$ & $\begin{array}{c}\text { Hardness } \\
\left(\mathbf{k g} / \mathbf{c m}^{\mathbf{2}}\right) \pm \mathbf{S D}\end{array}$ & $\begin{array}{c}\text { Friability } \\
\mathbf{( \% )} \pm \mathbf{S D}\end{array}$ & $\begin{array}{c}\text { Drug Content } \\
\mathbf{( \% )} \pm \mathbf{S D}\end{array}$ \\
\hline F-1 & $2.30 \pm 0.35$ & 1.93 & $5.22 \pm 0.01$ & $0.32 \pm 0.01$ & $99.25 \pm 0.40$ \\
F-2 & $2.32 \pm 0.45$ & 1.82 & $5.72 \pm 0.36$ & $0.76 \pm 0.01$ & $99.13 \pm 0.25$ \\
F-3 & $2.35 \pm 0.37$ & 1.71 & $6.02 \pm 0.01$ & $0.82 \pm 0.01$ & $99.15 \pm 0.16$ \\
F-4 & $2.30 \pm 0.39$ & 1.85 & $5.53 \pm 0.36$ & $0.66 \pm 0.01$ & $99.30 \pm 0.41$ \\
F-5 & $2.35 \pm 0.44$ & 2.19 & $5.55 \pm 0.35$ & $0.42 \pm 0.01$ & $98.48 \pm 0.41$ \\
F-6 & $2.33 \pm 0.43$ & 1.83 & $5.76 \pm 0.36$ & $0.49 \pm 0.01$ & $99.10 \pm 0.49$ \\
F-7 & $2.35 \pm 0.38$ & 2.30 & $5.88 \pm 0.33$ & $0.61 \pm 0.01$ & $98.58 \pm 0.52$ \\
F-8 & $2.32 \pm 0.29$ & 1.98 & $5.55 \pm 0.32$ & $0.45 \pm 0.01$ & $99.30 \pm 0.44$ \\
F-9 & $2.31 \pm 0.55$ & 1.76 & $5.52 \pm 0.36$ & $0.59 \pm 0.01$ & $98.64 \pm 0.06$ \\
F-10 & $2.35 \pm 0.52$ & 1.86 & $5.78 \pm 0.33$ & $0.60 \pm 0.01$ & $98.56 \pm 0.56$ \\
F-11 & $2.32 \pm 0.56$ & 2.10 & $5.58 \pm 0.32$ & $0.49 \pm 0.01$ & $98.81 \pm 0.58$ \\
F-12 & $2.31 \pm 0.33$ & 1.94 & $5.54 \pm 0.36$ & $0.55 \pm 0.01$ & $99.11 \pm 0.44$ \\
\hline
\end{tabular}

All values are mean \pm standard deviation (SD) for $n=3$ determination 
Preparation and in vitro \& in vivo evaluation of cephalexin matrix tablets

TABLE IV - In vitro dissolution profile for formulations F-1 To F-12 ( \pm SD)

\begin{tabular}{|c|c|c|c|c|c|c|c|c|c|c|c|c|}
\hline Time (h) & F-1 & F-2 & F-3 & F-4 & F-5 & F-6 & F-7 & F-8 & F-9 & F-10 & F-11 & F-12 \\
\hline 1 & $\begin{array}{l}18.66 \\
\pm 0.19\end{array}$ & $\begin{array}{l}16.08 \\
\pm 0.15\end{array}$ & $\begin{array}{l}21.11 \\
\pm 0.14\end{array}$ & $\begin{array}{l}15.48 \\
\pm 0.16\end{array}$ & $\begin{array}{l}25.11 \\
\pm 0.15\end{array}$ & $\begin{array}{c}26.7 \\
\pm 0.21\end{array}$ & $\begin{array}{l}25.24 \\
\pm 0.13\end{array}$ & $\begin{array}{l}21.03 \\
\pm 0.13\end{array}$ & $\begin{array}{l}18.59 \\
\pm 0.12\end{array}$ & $\begin{array}{l}20.25 \\
\pm 0.19\end{array}$ & $\begin{array}{l}20.60 \\
\pm 0.16\end{array}$ & $\begin{array}{l}15.09 \\
\pm 0.13\end{array}$ \\
\hline 2 & $\begin{array}{l}29.33 \\
\pm 0.12 \\
\end{array}$ & $\begin{array}{l}26.19 \\
\pm 0.19 \\
\end{array}$ & $\begin{array}{l}27.18 \\
\pm 0.18 \\
\end{array}$ & $\begin{array}{l}25.33 \\
\pm 0.24 \\
\end{array}$ & $\begin{array}{l}28.21 \\
\pm 0.26 \\
\end{array}$ & $\begin{array}{c}28.9 \\
\pm 0.16 \\
\end{array}$ & $\begin{array}{l}28.47 \\
\pm 0.16 \\
\end{array}$ & $\begin{array}{r}26.75 \\
\pm 0.18 \\
\end{array}$ & $\begin{array}{r}24.55 \\
\pm 0.15 \\
\end{array}$ & $\begin{array}{r}24.34 \\
\pm 0.12 \\
\end{array}$ & $\begin{array}{l}26.10 \\
\pm 0.13 \\
\end{array}$ & $\begin{array}{r}23.48 \\
\pm 0.15 \\
\end{array}$ \\
\hline 3 & $\begin{array}{l}56.02 \\
\pm 0.26 \\
\end{array}$ & $\begin{array}{l}43.25 \\
\pm 0.22 \\
\end{array}$ & $\begin{array}{l}45.55 \\
\pm 0.15 \\
\end{array}$ & $\begin{array}{l}39.05 \\
\pm 0.16\end{array}$ & $\begin{array}{l}49.65 \\
\pm 0.21 \\
\end{array}$ & $\begin{array}{l}49.61 \\
\pm 0.12 \\
\end{array}$ & $\begin{array}{l}50.78 \\
\pm 0.12 \\
\end{array}$ & $\begin{array}{r}52.74 \\
\pm 0.15 \\
\end{array}$ & $\begin{array}{l}50.21 \\
\pm 0.19 \\
\end{array}$ & $\begin{array}{l}50.44 \\
\pm 0.13 \\
\end{array}$ & $\begin{array}{l}50.24 \\
\pm 0.18 \\
\end{array}$ & $\begin{array}{l}50.84 \\
\pm 0.13 \\
\end{array}$ \\
\hline 4 & $\begin{array}{l}57.48 \\
\pm 0.18 \\
\end{array}$ & $\begin{array}{l}54.63 \\
\pm 0.20\end{array}$ & $\begin{array}{l}53.29 \\
\pm 0.12 \\
\end{array}$ & $\begin{array}{l}40.26 \\
\pm 0.18 \\
\end{array}$ & $\begin{array}{l}51.98 \\
\pm 0.12 \\
\end{array}$ & $\begin{array}{l}55.01 \\
\pm 0.18 \\
\end{array}$ & $\begin{array}{l}56.06 \\
\pm 0.18 \\
\end{array}$ & $\begin{array}{r}57.84 \\
\pm 0.12 \\
\end{array}$ & $\begin{array}{l}55.40 \\
\pm 0.12 \\
\end{array}$ & $\begin{array}{r}55.79 \\
\pm 0.18 \\
\end{array}$ & $\begin{array}{l}56.19 \\
\pm 0.15\end{array}$ & $\begin{array}{l}55.68 \\
\pm 0.12 \\
\end{array}$ \\
\hline 5 & $\begin{array}{l}59.37 \\
\pm 0.20 \\
\end{array}$ & $\begin{array}{l}60.46 \\
\pm 0.25 \\
\end{array}$ & $\begin{array}{r}60.73 \\
\pm 0.16 \\
\end{array}$ & $\begin{array}{l}56.89 \\
\pm 0.12 \\
\end{array}$ & $\begin{array}{r}57.23 \\
\pm 0.18 \\
\end{array}$ & $\begin{array}{l}57.19 \\
\pm 0.16 \\
\end{array}$ & $\begin{array}{r}59.47 \\
\pm 0.14 \\
\end{array}$ & $\begin{array}{l}60.73 \\
\pm 0.20 \\
\end{array}$ & $\begin{array}{r}58.94 \\
\pm 0.16 \\
\end{array}$ & $\begin{array}{l}60.84 \\
\pm 0.14 \\
\end{array}$ & $\begin{array}{l}60.35 \\
\pm 0.14 \\
\end{array}$ & $\begin{array}{l}60.78 \\
\pm 0.14 \\
\end{array}$ \\
\hline 6 & $\begin{array}{l}60.54 \\
\pm 0.23 \\
\end{array}$ & $\begin{array}{c}64.4 \\
\pm 0.22 \\
\end{array}$ & $\begin{array}{r}69.33 \\
\pm 0.13 \\
\end{array}$ & $\begin{array}{r}65.84 \\
\pm 0.13 \\
\end{array}$ & $\begin{array}{r}60.00 \\
\pm 0.15 \\
\end{array}$ & $\begin{array}{r}59.53 \\
\pm 0.13 \\
\end{array}$ & $\begin{array}{r}59.89 \\
\pm 0.16 \\
\end{array}$ & $\begin{array}{r}66.30 \\
\pm 0.15 \\
\end{array}$ & $\begin{array}{r}60.13 \\
\pm 0.13 \\
\end{array}$ & $\begin{array}{r}63.57 \\
\pm 0.26 \\
\end{array}$ & $\begin{array}{l}63.71 \\
\pm 0.25 \\
\end{array}$ & $\begin{array}{r}65.42 \\
\pm 0.13 \\
\end{array}$ \\
\hline 7 & $\begin{array}{l}65.79 \\
\pm 0.21 \\
\end{array}$ & $\begin{array}{c}69.8 \\
\pm 0.18 \\
\end{array}$ & $\begin{array}{r}75.17 \\
\pm 0.13 \\
\end{array}$ & $\begin{array}{l}73.96 \\
\pm 0.13 \\
\end{array}$ & $\begin{array}{l}60.59 \\
\pm 0.14 \\
\end{array}$ & $\begin{array}{l}63.05 \\
\pm 0.18 \\
\end{array}$ & $\begin{array}{l}54.16 \\
\pm 0.21 \\
\end{array}$ & $\begin{array}{l}67.22 \\
\pm 0.16 \\
\end{array}$ & $\begin{array}{l}63.82 \\
\pm 0.24 \\
\end{array}$ & $\begin{array}{r}69.46 \\
\pm 0.16 \\
\end{array}$ & $\begin{array}{l}69.58 \\
\pm 0.20 \\
\end{array}$ & $\begin{array}{r}70.96 \\
\pm 0.18 \\
\end{array}$ \\
\hline 8 & $\begin{array}{l}69.44 \\
\pm 0.20 \\
\end{array}$ & $\begin{array}{l}72.57 \\
\pm 0.21 \\
\end{array}$ & $\begin{array}{r}75.46 \\
\pm 0.18 \\
\end{array}$ & $\begin{array}{l}79.16 \\
\pm 0.17 \\
\end{array}$ & $\begin{array}{l}65.26 \\
\pm 0.19 \\
\end{array}$ & $\begin{array}{l}67.99 \\
\pm 0.12 \\
\end{array}$ & $\begin{array}{l}69.88 \\
\pm 0.15 \\
\end{array}$ & $\begin{array}{l}69.87 \\
\pm 0.13 \\
\end{array}$ & $\begin{array}{l}67.39 \\
\pm 0.19 \\
\end{array}$ & $\begin{array}{r}73.45 \\
\pm 0.13 \\
\end{array}$ & $\begin{array}{l}76.15 \\
\pm 0.26\end{array}$ & $\begin{array}{l}78.49 \\
\pm 0.14 \\
\end{array}$ \\
\hline 9 & $\begin{array}{r}71.92 \\
\pm 0.18 \\
\end{array}$ & $\begin{array}{l}74.61 \\
\pm 0.12 \\
\end{array}$ & $\begin{array}{r}77.65 \\
\pm 0.26 \\
\end{array}$ & $\begin{array}{l}82.95 \\
\pm 0.12 \\
\end{array}$ & $\begin{array}{r}70.22 \\
\pm 0.22 \\
\end{array}$ & $\begin{array}{r}71.63 \\
\pm 0.23 \\
\end{array}$ & $\begin{array}{r}79.37 \\
\pm 0.13 \\
\end{array}$ & $\begin{array}{r}71.93 \\
\pm 0.12 \\
\end{array}$ & $\begin{array}{r}73.68 \\
\pm 0.14 \\
\end{array}$ & $\begin{array}{r}78.35 \\
\pm 0.17 \\
\end{array}$ & $\begin{array}{r}85.13 \\
\pm 0.19 \\
\end{array}$ & $\begin{array}{r}88.26 \\
\pm 0.12 \\
\end{array}$ \\
\hline 10 & $\begin{array}{r}78.19 \\
\pm 0.24 \\
\end{array}$ & $\begin{array}{l}79.27 \\
\pm 0.21 \\
\end{array}$ & $\begin{array}{r}79.98 \\
\pm 0.18 \\
\end{array}$ & $\begin{array}{l}91.65 \\
\pm 0.21 \\
\end{array}$ & $\begin{array}{r}73.28 \\
\pm 0.13 \\
\end{array}$ & $\begin{array}{l}78.78 \\
\pm 0.16 \\
\end{array}$ & $\begin{array}{l}85.06 \\
\pm 0.17 \\
\end{array}$ & $\begin{array}{r}77.53 \\
\pm 0.24 \\
\end{array}$ & $\begin{array}{r}75.87 \\
\pm 0.25 \\
\end{array}$ & $\begin{array}{r}82.89 \\
\pm 0.15 \\
\end{array}$ & $\begin{array}{r}88.29 \\
\pm 0.24 \\
\end{array}$ & $\begin{array}{l}92.84 \\
\pm 0.14 \\
\end{array}$ \\
\hline 11 & $\begin{array}{l}86.07 \\
\pm 0.21 \\
\end{array}$ & $\begin{array}{l}85.42 \\
\pm 0.16 \\
\end{array}$ & $\begin{array}{r}88.48 \\
\pm 0.17 \\
\end{array}$ & $\begin{array}{l}96.47 \\
\pm 0.16 \\
\end{array}$ & $\begin{array}{r}83.78 \\
\pm 0.12 \\
\end{array}$ & $\begin{array}{l}84.47 \\
\pm 0.13 \\
\end{array}$ & $\begin{array}{l}87.25 \\
\pm 0.20 \\
\end{array}$ & $\begin{array}{l}88.86 \\
\pm 0.26 \\
\end{array}$ & $\begin{array}{l}80.99 \\
\pm 0.16 \\
\end{array}$ & $\begin{array}{r}88.43 \\
\pm 0.13 \\
\end{array}$ & $\begin{array}{l}92.66 \\
\pm 0.22 \\
\end{array}$ & $\begin{array}{l}94.26 \\
\pm 0.16 \\
\end{array}$ \\
\hline 12 & $\begin{array}{l}92.34 \\
\pm 0.18\end{array}$ & $\begin{array}{l}93.89 \\
\pm 0.18\end{array}$ & $\begin{array}{l}94.36 \\
\pm 0.15\end{array}$ & $\begin{array}{c}100.34 \\
\pm 0.14\end{array}$ & $\begin{array}{l}89.91 \\
\pm 0.13\end{array}$ & $\begin{array}{l}90.60 \\
\pm 0.18\end{array}$ & $\begin{array}{l}91.63 \\
\pm 0.12\end{array}$ & $\begin{array}{l}92.50 \\
\pm 0.20\end{array}$ & $\begin{array}{l}92.48 \\
\pm 0.13\end{array}$ & $\begin{array}{l}95.41 \\
\pm 0.13\end{array}$ & $\begin{array}{l}95.48 \\
\pm 0.20\end{array}$ & $\begin{array}{l}97.47 \\
\pm 0.13\end{array}$ \\
\hline
\end{tabular}

All values are mean \pm standard deviation (SD) for $\mathrm{n}=3$ determination

TABLE V - Release kinetics of formulated matrix tablets

\begin{tabular}{cccc}
\hline \multirow{2}{*}{ Formulation Code } & \multicolumn{2}{c}{ Correlation Coefficient } & $\begin{array}{c}\text { Zero Order Release Rate } \\
\text { constant, } \mathbf{K}_{\mathbf{0}}\left(\mathbf{h}^{-1}\right)\end{array}$ \\
\cline { 2 - 3 } F-1 & Zero order & First order & 6.0380 \\
F-2 & 0.9548 & 0.9524 & 6.8202 \\
F-3 & 0.9670 & 0.9627 & 6.6801 \\
F-4 & 0.9693 & 0.9683 & 8.0433 \\
F-5 & 0.9899 & 0.9545 & 5.5833 \\
F-6 & 0.9730 & 0.9535 & 5.6471 \\
F-7 & 0.9784 & 0.9641 & 6.0809 \\
F-8 & 0.9688 & 0.9613 & 6.2138 \\
F-9 & 0.9559 & 0.9538 & 6.1734 \\
F-10 & 0.9596 & 0.9460 & 6.7321 \\
F-11 & 0.9701 & 0.9569 & 7.0603 \\
F-12 & 0.9763 & 0.9747 & 7.7538 \\
\hline
\end{tabular}


with $\mathrm{K}_{0}$ values between 8.0433 and 5.5833. The in vitro release profiles of drug from all the formulations could be better expressed by Higuchi's equation, as the plots showed high linearity with $\mathrm{R}^{2}$ values between 0.9753 and 0.9914. It indicates that diffusion mechanism involved in the release of the drug from the tablets. To confirm the diffusion mechanism, the data were fit into Korsmeyer Peppas equation. From the slope 'n' values are found ranging from 0.4655 to 0.7473 (Table VI). Data obtained from all necessary parameters, it was concluded that the formulation F-4 (EC: HPMC K4M in $5 \mathrm{mg}$ : $20 \mathrm{mg}$ ratio) released $100.34 \%$ of cephalexin in $12 \mathrm{~h}$ could be optimized as the best formulation as it prevailed cent percentage release of the drug. As per release mechanism studies, the drug release pattern followed non-fickian diffusion.

TABLE VI - Diffusion characteristics of formulated matrix tablets

\begin{tabular}{|c|c|c|c|}
\hline \multirow{3}{*}{$\begin{array}{l}\text { Formulation } \\
\text { code }\end{array}$} & \multicolumn{3}{|c|}{ Kinetic models } \\
\hline & \multirow{2}{*}{$\frac{\text { Higuchi }}{\mathbf{R}^{2}}$} & \multicolumn{2}{|c|}{ Peppas model } \\
\hline & & $\mathbf{R}^{2}$ & $\mathbf{n}$ \\
\hline F-1 & 0.9774 & 0.9768 & 0.5633 \\
\hline $\mathrm{F}-2$ & 0.9914 & 0.9906 & 0.7074 \\
\hline F-3 & 0.9893 & 0.9843 & 0.5939 \\
\hline F-4 & 0.9943 & 0.9968 & 0.7473 \\
\hline F-5 & 0.9834 & 0.9823 & 0.4879 \\
\hline F-6 & 0.9860 & 0.9784 & 0.4655 \\
\hline F-7 & 0.9753 & 0.9752 & 0.5053 \\
\hline F-8 & 0.9795 & 0.9802 & 0.5781 \\
\hline F-9 & 0.9797 & 0.9749 & 0.5955 \\
\hline F-10 & 0.9878 & 0.9800 & 0.6105 \\
\hline F-11 & 0.9909 & 0.9842 & 0.6162 \\
\hline F-12 & 0.9890 & 0.9811 & 0.7382 \\
\hline
\end{tabular}

Required pharmacokinetic parameters were estimated as shown in the Table VII. A graph was plotted to establish correlation in between in vitro zero order dissolution rate constant $\left(\mathrm{K}_{0}\right)$ and in vivo maximum serum concentration $\left(\mathrm{C}_{\max }\right)$, of the pure and the optimized formulation of cephalexin and the value was 0.9950 (in Figure 7). The elimination rate constants $\left(\mathrm{K}_{\mathrm{el}}\right)$ of matrix tablets and the pure drug were $0.2289 \mathrm{~h}^{-1}$ and $0.693 \mathrm{~h}^{-1}$ respectively. The elimination half life $\left(\mathrm{t}_{1 / 2}\right)$ of the matrix tablets and the pure drug were $3.027 \mathrm{~h}$ and $1 \mathrm{~h}$ respectively. The $\mathrm{t}_{\max }$ values for the pure drug and matrix tablets were $1 \mathrm{~h}$ and $8 \mathrm{~h}$ respectively. From the in vivo pharmacokinetic studies, three time reduction in elimination rate indicating a slow elimination of the drug from the body. Based on the elimination half life $\left(t_{1 / 2}\right)$ of the matrix tablets and the pure drug, it indicated slow elimination and long residence time of the drug in the body. Moreover, AUMC of optimized tablet was increased more than twofold in comparison to pure drug. The absorption rate constant $\mathrm{K}_{\mathrm{a}}$ of matrix tablets was slower than the pure drug, indicated a slower absorption of the drug. In spite of that, there was no significant change in $\mathrm{C}_{\max }$ of the pure drug and matrix tablets. Significant changes in $\mathrm{K}_{\mathrm{el}}, \mathrm{t}_{1 / 2}, \mathrm{~K}_{\mathrm{a}}, \mathrm{t}_{\max }$ and AUMC values of the drug when administered as matrix tablets clearly indicated that the matrix tablets developed in the study showed a controlled release of the drug confirming the results of in vitro studies with their correlation coefficient value 0.9950 . A good correlation was observed between in vitro and in vivo parameters.

TABLE VII - Pharmacokinetic parameters of cephalexin

\begin{tabular}{lcc}
\hline Parameters & Pure cephalexin & Matrix tablets \\
\hline $\mathrm{K}_{\mathrm{el}}\left(\mathrm{h}^{-1}\right)$ & 0.6930 & 0.2289 \\
$\mathrm{~T}_{1 / 2}(\mathrm{~h})$ & 1 & 3.027 \\
$\mathrm{~K}_{\mathrm{a}}\left(\mathrm{h}^{-1}\right)$ & 3.580 & 0.3784 \\
$\mathrm{~T}_{\max }(\mathrm{h})$ & 1 & 8 \\
$\mathrm{C}_{\max }(\mu \mathrm{g} / \mathrm{mL})$ & 1.5670 & 1.3440 \\
$\mathrm{AUMC}(\mu \mathrm{g} \mathrm{h} / \mathrm{mL})$ & 49.1160 & 127.354 \\
\hline
\end{tabular}

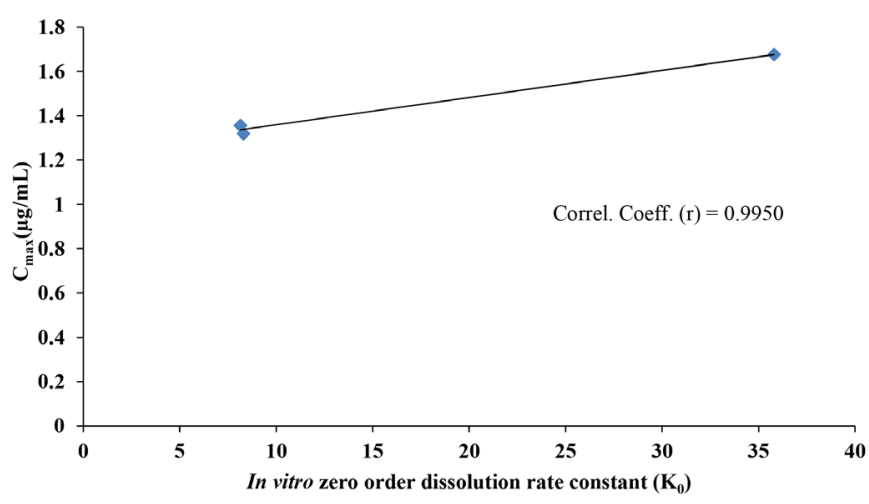

FIGURE 7- Correlation between in vitro zero order dissolution rate constant $\left(\mathrm{K}_{0}\right)$ and in vivo maximum serum concentration $\left(\mathrm{C}_{\max }\right)$ of the pure and optimized controlled release formulation of cephalexin.

\section{CONCLUSION}

Cephalexin controlled-release matrix tablets were successfully designed using hydrophilic and hydrophobic polymer. There were no incompatibility interactions 
in between polymers and drug. Results from in vivo pharmacokinetic parameters confirmed the drug release from the cephalexin matrix tablets in a controlled manner with longer residence time and having effective pharmacological action. There was good in vitro and in vivo correlations as per obtained datas. It can also be concluded that mixture of lower viscosity grade, i.e., HPMC K4M with EC (mixture about 7\% of a tablet weight) in matrix form, extended the drug release from the dosage form upto $12 \mathrm{~h}$ completely thereby increasing patient compliance and reduces the adverse effects.

\section{FINANCIAL SUPPORT AND SPONSORSHIP}

None

\section{REFERENCES}

Andreopopulas AG, Tarantilli PA. Xanthan gum as a carrier for controlled release of drug. J Biomater Appl. 2001;16(1):35-8.

Aulton ME. Pharmaceutics: the science of dosage form design. 2nd ed. Churchill: Livingstone; 2002. p. 133-34.

Basak SC, Shrinivasa R, Manavalan R, Rao P. Controlled release HPMC matrix tablet of propranolol HCl. Indian J Pharm Sci. 2004;66:827-33.

Chaudhari PD. Formulation and Evaluation of fast dissolving tablet of famotidine. Indian Drugs. 2005;42:641-49.

Chugh I, Seth N, Rana AC, Gupta S. Oral sustained release drug delivery systems: an overview. Int Res J Pharm. 2012;2:57-62.

Cooper J, Gunn C. Powder flow and compaction. In: Carter SJ. editors, Tutorial Pharmacy. New Delhi: CBS Publishers and Distributors; 1986. p. 211-33.

Gennaro AR. Remington: the science and practice of pharmacy. 20th ed. USA: Mac Publishing Company, Easton PA; 2001. p. 627.

Higuchi T. Mechanisms of sustained action medication: Theoretical analysis of rate release of solid drugs dispersed in solid matrices. J Pharm Sci. 1963;52:1145-49.

Indian Pharmacopoeia. Ministry of Health and Family Welfare. Govt. of India, New Delhi: Controller of Publication; 2010. p. 185.
Korsmeyer RW, Gurny R, Doelker E, Buri P, Peppas NA. Mechanisms of solute release from porous hydrophilic polymers. Int J Pharm. 1983;15(1):25-35.

Krishanaiah YS, Lath K, Nageshwara L, Karthikeyan RS, Satyanarayana VBP. Development of colon target oral guar gum matrix tablet of Albendazole for the treatment of Helminthiasis. Indian J Pharm Sci. 2003;65(4):378-85.

Lachman L, Lieberman HA. The theory and practice of industrial pharmacy. Special Indian Ed. India: 2009. p. 300,317.

Parikh DM. Handbook of pharmaceutical granulation technology. $2^{\text {nd }}$ ed. North Carolina, USA: Synthon Pharmaceuticals Inc; 2005. p. 191-2.

Raparla DV, Murthy TE. Formulation and evaluation of oral controlled release Glimepiride matrix tablets. Adv Pharmacol Toxicol. 2007;8:59-62.

Reddy BBK, Nagoji KEV, Patnaik C. Studies on controlled release formulations of a macrolide antibiotic drug: Influence of HPMC of different grades as matrix former. World J Pharm Sci. 2015;3(10):2058-68.

Reddy BBK, Nagoji KEV, Sahoo S. Formulation design and evaluation of cephalexin controlled release matrix tablets. World J Pharm Res. 2016;5:1193-1204.

Rezal MD, Qadir MA, Haider SS. Comparative evaluation of polymers as matrix for controlled release drug delivery. J Pharm Pharma Sci. 2003;6(2):274-91.

Shabaraya AR, Narayanacharyulu R. Design and evaluation of chitason matrix of metoprolol tartrate for sustained release. J Pharm Pharm Sci. 2008;8:231-36.

Shirwaikar AA, Jacob S, Grover V. Formulation and evaluation of sustained release tablets using an insoluble rosin matrix system. Indian J Pharm Sci. 2005;67:80-3.

Sirisolla J, Ramanamurthy KV. Formulation and evaluation of cefixime trihydrate matrix tablets using HPMC, Sodium CMC, ethyl cellulose. Indian J Pharm Sci. 2015;77(3):321-27.

Tripathi KD. Essential of medical pharmacology. 7th ed. New Delhi: Jayee Brothers Medical Publishers; 2013. p. 726. 
Vijay J, Sahadevan JT, Prabhakaran R, Mehra Gilhotra R. Formulation and evaluation of cephalexin extended-release matrix tablets using hydroxy propyl methyl cellulose as ratecontrolling Polymer. J Young Pharm. 2012;4(1):3-12.
Wagner JG. Interpretation of percent dissolved-time plots derived from in vitro testing of conventional tablets and capsules. J Pharm Sci. 1969;58(10):1253-57.

Received for publication on 19 $9^{\text {th }}$ May 2017 Accepted for publication on $20^{\text {th }}$ September 2017 